KS. JACEK KEMPA

Uniwersytet Śląski w Katowicach

https://orcid.org/0000-0002-1965-785X

\title{
KRYTYCZNE FUNKCJE TEOLOGII W PERSPEKTYWIE PRZYSZŁOŚCI
}

\section{WSTĘPNE WYJAŚNIENIA}

Refleksja nad zaproponowanym tematem kryje w sobie dwie podstawowe trudności. Pierwsza wiąże się z mówieniem o przyszłości. Prognozy nie stanowią łatwego obszaru w dyskursie, który podnosi roszczenie do ścisłości. By umniejszyć wpływ subiektywnych projekcji na niniejsze przedstawienie problematyki, podejmę próbę oparcia się na diagnozie sytuacji współczesnej, warunkującej w kilku wymiarach rozwój teologii, a w której dają się zaobserwować trendy zapowiadające prawdopodobną nieodległą przyszłość. Na podstawie tak stworzonego szkicu tendencji będę starał się o ostrożną i szkicową ekstrapolację ustaleń poczynionych w odniesieniu do obecnej sytuacji teologii.

Druga trudność wynika z próby mówienia o teologii jako takiej. W świecie nauki strzeżemy się raczej przed wysuwaniem tez dotyczących szerszego zakresu niż ten związany z własną specjalizacją. Tak też jest w przypadku teologii i namysłu nad jej krytycznymi funkcjami. Łatwo wysuwają się na czoło wąskospecjalistyczne kwestie. A jednak refleksja nad teologią ujmowaną jako pewna całość wydaje się dziś i w przyszłości bardzo potrzebna. Warto zauważyć, że to już pierwsza prognoza, o formalnym charakterze. Jeśli rozumiemy teologię chrześcijańską jako intellectus fidei, to w świecie, w którym fides straciła wiele ze swojej społeczno-kulturowej oczywistości i zapewne - rozumiana w religijno-konfesyjnym sensie - nadal będzie tracić, wzmagać się będzie potrzeba wskazywania na jej wartość, która tylko jej jest właściwa, a zarazem na jej istotne powiązania z tą rzeczywistością, którą interpretacja areligijna postrzega jako samowystarczalną.

Niniejsza propozycja ujęcia krytycznych funkcji teologii nawiązuje do tezy o jej jedności. W obliczu otwierającego się szerokiego zakresu szczegółowych tematów niniejsza refleksja będzie skoncentrowana na naszkicowaniu ogólnych diagnoz. Stąd nie odwoła się do specyficznych zagadnień, związanych z „regionalnymi” zadaniami niektórych specjalizacji teologicznych czy z poszczególnymi, „gorącymi”, 
dyskutowanymi kwestiami. Zupełnie marginalnie - i tylko jako przykłady - pojawią się tu w formie haseł pewne specyficzne, wąskie zagadnienia.

Drobnego wyjaśnienia domaga się termin „krytyka”. Podejrzenie o dwojakie jego znaczenie znajduje potwierdzenie już w lekturze słowników i encyklopedii wydanych przez PWN. Słowniki wysuwają na czoło znaczenie: ,surowa lub negatywna ocena". Encyklopedia odwrotnie, odwołuje się do drugiego znaczenia, stwierdzając, że to ,analiza i ocena pewnej dziedziny ludzkiej działalności i jej wytworów ze względu na określone wartości"’2. Przy okazji wskazuje na grecki źródłosłów kritike techne jako „sztuki osądzania, rozstrzygania”. Można przypuszczać, że to znamienne rozejście się definicji odpowiada charakterowi tych dwóch typów publikacji: encyklopedia zabiega o ujęcie normatywne, a słownik zdaje sprawę z realnej praktyki językowej. Warto zatrzymać się przy tym fakcie, bo on dobrze oddaje pewien ważny moment w temacie głównym: sformułowanie „krytyczna funkcja teologii" będzie rozumiane wyłącznie w odniesieniu do sztuki osądzania i rozstrzygania. Zakłada ona oczywiście także możliwość negatywnej oceny, ale się do niej nie ogranicza, a zawsze domaga się odpowiedniej argumentacji, która to z kolei sama może być poddana ocenie. Zostaje tym samym przywołana właściwa nauce pokora w poszukiwaniu prawdy i intelektualna rzetelność.

Problem określony w temacie jest bardzo rozległy. Stąd jego podjęcie jest zaledwie próbą zarysowania inspiracji, a z pewnością nie dąży do wyczerpania zagadnienia nawet na najbardziej ogólnej płaszczyźnie. Ze względu na wspomnianą obszerność podjętej kwestii zostaje tu zaproponowane systematyczne podejście do niej przez wykorzystanie przecinających się dwu różnych perspektyw. Obie odnoszą się do formalnego rozróżnienia ad intra - ad extra, jednak pozostają różne. Jedna ujmuje rozróżnienie ad intra - ad extra w rozumieniu: teologia jako nauka krytyczna wobec siebie samej (ad intra) - teologia jako metoda i treść krytycznego, profetycznego przekazu (ad extra). Druga perspektywa odsłania dwa obszary, które można opisać jako „teologia w Kościele” (ad intra) i „teologia w świecie” (ad extra). Z przecięcia się tych dwu perspektyw wyrastają cztery obszary tematyczne, w których - jak się wydaje - problematyka krytycznych funkcji teologii prezentuje swoje różne oblicza.

Zaczniemy od spojrzenia na teologię krytyczną wobec siebie samej (czyli ad intra), widzianą w jej relacji do całości świata nauk (czyli „teologia w świecie”). Potem podejmiemy temat wewnętrznej krytyki teologii, prowadzonej z punktu widzenia jej własnej specyfiki i usytuowania w środowisku wiary Kościoła. Następnie perspektywa pierwsza ulegnie odwróceniu i zostanie postawione pytanie o krytyczne zadania teologii wobec wiary Kościoła i dalej: wobec ,świata”.

1 M. Bańka (red.), Wielki słownik wyrazów obcych PWN, Warszawa: Wydawnictwo Naukowe PWN 2005, s. 701. Por. podobnie: A. Markowski (red.), Wielki słownik poprawnej polszczyzny PWN, Warszawa: Wydawnictwo Naukowe PWN 2006, s. 446.

2 J. Wojnowski (red.), Wielka encyklopedia PWN, Warszawa 2003, s. 87. 


\section{ROZWINIĘCIE PIERWSZE: \\ TEOLOGIA KRYTYCZNA WOBEC SIEBIE}

\subsection{TEOLOGIA JAKO NAUKA STOSUJE FORMALNE KRYTERIA KRYTYCZNEGO MYŚLENIA}

Pierwszy krąg zagadnień związany z teologią jako nauką jest niezwykle szeroki, jeśli ujmować go w pytaniu: jakie impulsy dla krytyczności teologii wobec siebie samej przychodzą od świata? Dlatego szerokie i niejednoznaczne pojęcie ,świat" sprowadzimy do „świata nauk”. Wyzwanie nadal pozostaje ogromne, ze względu na niezwykle rozwiniętą przestrzeń nauki. Mimo to pojawia się tutaj w miarę wyraźna płaszczyzna uwspólniająca, z której można wysunąć ogólne krytyczne postulaty pod adresem teologii. Otóż, zanim mogłyby zostać postawione teologii liczne szczegółowe pytania ze strony poszczególnych nauk, pojawia się przychodzące z owej wspólnej dla nich płaszczyzny pytanie o dyscyplinę metodologiczną. To ona jest istotnym wskaźnikiem rzetelności w naukach. Tak samo dzieje się w teologii. Metodologia dostarcza narzędzi do rzetelnego stosunku do źródeł, rzetelności we wnioskowaniu, rzetelnego odnoszenia się do poglądów, nad którymi prowadzi się debatę. Ten krąg zagadnień domagałby się własnego rozszerzenia; w krótkim opracowaniu nie ma potrzeby odnosić się do szerokiej dyskusji o poszczególnych problemach, której echa i rezultaty znajdziemy w podręcznikach ${ }^{3}$.

Jeśli jednak odnosimy się do postulatów płynących ze świata innych nauk, a zatem do czysto formalnego ujmowania zasad metodologii, to trzeba zatrzymać się przy kwestii leżącej o poziom głębiej, czyli problemu krytycznego namysłu nad uzasadnieniami kryteriów metodologii teologii. Warto to uczynić co najmniej z dwóch powodów. Pierwszy ma charakter formalny: w teologii, tak jak w innych naukach, nie wystarcza mechaniczne stosowanie jednego ze standardów metody teologicznej ani jego bezrefleksyjny wybór, nawet przy najbardziej sumiennym zastosowaniu. Zawsze potrzebny (a przynajmniej wskazany) jest głębszy namysł nad metodą, a więc nad tym, jaka droga najlepiej odpowiada przedmiotowi badań i ich celowi. Ten moment namysłu metodologicznego doskonale odzwierciedla pierwszy poziom krytyczności, charakterystyczny tak dla teologii, jak i dla wszystkich nauk. Tym samym jest to najszerszy poziom wspólny. Specyfika pojedynczej dyscypliny nie przeszkadza w tym, by wspólne wszystkim naukom, krytyczne myślenie o własnej metodologii pomagało także w rozwoju teologii. Może ono wpływać mobilizująco na jej własną „metodologiczną odpowiedzialność” w ogóle, a w szczególności tam, gdzie w spotkaniu z naukami szczegółowymi trzeba zdać sprawę z rzetelności, a także ze specyfiki własnego postępowania badawczego.

3 Np. J. Majka, Metodologia nauk teologicznych, Wrocław: TUM 1995; por. J. Wicks, Wprowadzenie do metody teologicznej, Kraków: Wydawnictwo WAM 1995. 
Wspomniane fundamentalne powiązanie teologii z innymi naukami w przestrzeni formalnych wymogów pozwala na postawienie pytania idącego o krok dalej. Przywołuje tym samym drugi powód, dla którego warto się zatrzymać przy obowiązku krytyczności teologii jako nauki. Chodzi o uprawianie teologii w kontekście rezultatów nauk - o potrzebę, możliwości i granice takiego działania. W zasadzie to nie nauka (nauki) pyta teologię o wiarygodność jej tez, ale to teologia jest zmobilizowana do pytania siebie, czy w kontekście wiedzy o świecie, zdobywanej w rozwijających się naukach, potrafi wiarygodnie uchwycić to, co jest przedmiotem chrześcijańskiej wiary. Oczywiście, nie jest to nowe zagadnienie; nie pojawiło się ono dopiero w związku z rozwojem nauk nowożytnych. Przenikało ono przecież całą przeszłość poszukiwań prawdy o rzeczywistości. Przed pojawieniem się nauk szczegółowych i przed ich sukcesem w wyjaśnianiu świata taką rolę odgrywała filozofia. Jak długo jej wyjaśnienia świata jako całości były przyjmowane jako wystarczające, tak długo to ona budowała obraz świata. To w jego ramach możliwe było teologiczne opisywanie prawd wiary (oczywiście, ze względu na wielowiekowe wzajemne powiązania filozofii i teologii to oddziaływanie odbywało się w obu kierunkach). Obowiązek krytycznego myślenia teologicznego już wówczas wiązał się z koniecznością nawiązywania do wyjaśnień, które przynosiła filozofia. Zmiany w paradygmatach filozoficznego rozumienia rzeczywistości sprawiały konieczność nowych poszukiwań w teologii. Taki spektakularny, udany zwrot miał miejsce w okresie scholastycznym w związku ze spotkaniem nieznanej (bo zaginionej) wcześniej metafizyki arystotelesowskiej.

Rozwój nauk szczegółowych w nowożytności przyniósł teologii wielkie kryzysy. Wydarzały się one nie tyle ze względu na kwestionowanie teonomicznego rozumienia rzeczywistości przez nowe nauki (kwestią osobnej dyskusji jest ustalenie złożoności powiązań przyczynowo-skutkowych między rozwojem nauk, kryzysami teologii a zmianami w statusie poznania filozoficznego), ile ze względu na odrzucanie starego obrazu świata, na którym zbudowane były liczne teologiczne wyjaśnienia wiary. Trudno było odróżniać istotę tej prezentacji wiary od ram, w których została umieszczona. Mimo wytłumaczalnych w takich kryzysowych chwilach napięć i regresów w myśli teologicznej ostatecznie ona sama nie mogła odrzucić starego pytania, jak w obliczu obrazu świata wyłaniającego się ze skomplikowanej siatki twierdzeń wielu nauk racjonalnie prezentować wiarę: jak odpowiedzialnie wrócić do Anzelmowej formuły fides quaerens intellectum, nie kwestionując intelektu uformowanego na nowym obrazie świata.

Musiało upłynąć nieco czasu, by teologia katolicka głównego nurtu zaczęła bez uprzedzeń spoglądać na nauki szczegółowe i ich wyniki. Podobny proces dotyczy zresztą części uczestników debaty religia - nauka, stojących po stronie nauki ${ }^{4}$. Dopiero dzięki wzajemnemu otwarciu możliwa była sensowna, obustronna krytyka, w której obie strony zaczęły się nawzajem słuchać. Taka rzetelna konfrontacja

4 Por. M. Heller, Nowa fizyka i nowa teologia, Tarnów: Biblos 1992, s. 57-71. 
teologii ze światem nauk szczegółowych przyniosła konieczność nowej krytycznej refleksji teologii nad własną tożsamością i nad granicami przebiegającymi między nią a innymi naukami. Tu z pomocą przyszedł filozoficzny namysł nad różnicami w zakresach poznania charakterystycznych dla teologii i nauk. Mimo to okazuje się, że jest niemało szczegółowych zagadnień teologicznych, które nie pozwalają na łatwe obejście problemów na styku nauka - wiara, dokonywane przez zwrócenie uwagi na nieprzystawalność poznania teologicznego i naukowego, charakterystycznego dla nauk szczegółowych. W tych miejscach szczególnie wyraźnie widać, że obraz świata generowany przez nauki nowożytne, nawet jeśli nie sięga refleksji nad transcendencją, musi być uwzględniony w teologicznej interpretacji rzeczywistości, a tym samym domaga się krytycznej recepcji ${ }^{5}$. Debata nad relacjami nauka - wiara (a w pochodny sposób: nauki szczegółowe - teologia) weszła w nowy etap ${ }^{6}$.

Trzeba uznać, że dynamiczny rozwój nowożytnych nauk zmobilizował do krytycznego myślenia w obrębie teologii. Tym samym przyczynił się do odważnych i wartościowych poszukiwań teologicznych. Dzieje się to z całym ryzykiem chodzenia po nieznanych terenach i bolesnych sporów o tożsamość kościelnej teologii. Nie ma jednak dziś wyjścia: teologii współczesnej nie wolno zignorować istnienia nauk i ich opisu świata. $\mathrm{W}$ przeciwnym razie zrezygnuje ona z mówienia o Bogu w kontekście współczesnym, a więc z głównego swojego zadania. Nie należy tej deklaracji bliskości teologii z innymi naukami błędnie rozumieć jako zamachu na tożsamość teologii. Wystarczy uprzednio przywołać i przyjąć klasyczne postulaty topiki teologicznej, odnieść się do standardowych ścieżek rozumowania teologicznego, zaakceptować konstytutywne powiązania teologii z wiarą Kościoła, a wraz z tym przyjąć, że współczesne rozwinięcie teologii domaga się osadzenia we współczesnym obrazie świata. Warto też sobie postawić pytanie, w jaki sposób, w jakim zakresie, w jakich badaniach teologia może przyjąć metodologiczne propozycje współczesnych nauk. Wypada przyjąć jako bardzo prawdopodobne, że to wyzwanie do krytycznego uprawiania teologii w kontekście rozwoju nauk szczegółowych będzie narastało w przyszłości i otwierało nowe przestrzenie pytań.

5 Teologiczny namysł, w którym wiedzę naukową trudno potraktować jako „obojętną scenerię” dla „odrębnej” teologii, obejmuje problemy takie, jak: relacja duch - mózg, wolność - determinanty biologiczne, nauka o stworzeniu w obliczu współczesnej kosmologii itd.

6 Próby ustalenia typów relacji między nauką a teologią przedstawia I.G. Barbour, Jak układaja się stosunki między nauka a teologia? Część I, thum. S. Cyran i in., „Zagadnienia Filozoficzne w Nauce” 15 (1993), s. 3-22, Część II, thum. S. Cyran i in., „Zagadnienia Filozoficzne w Nauce” 16 (1994), s. 3-22. Por. też P. Polak, Teologia nauki w perspektywie metodologicznej, w: J. Mączka, P. Urbańczyk (red.), Teologia nauki, Kraków: Copernicus Center Press 2015, s. 27-29. Autor tego opracowania dyskutuje propozycję Barboura w szerszej perspektywie. Podobnie por.: R.J. Woźniak, Dogmatyka w perspektywie interdyscyplinarnej. Prolegomena teoretyczno-metodologiczne, w: R.J. Woźniak (red.), Dogmat i metoda. Wprowadzenie do badań interdyscyplinarnych $w$ teologii dogmatycznej, Kraków: Wydawnictwo WAM 2021, s. 33-35. 
Pytania pod adresem teologii przychodzą jednak nie tylko ze strony nowożytnych nauk przyrodniczych, opartych na empirii bądź budujących dla badań podstawy teoretyczne. Wezwanie do krytycznego namysłu teologicznego łatwo znaleźć także w obszarze humanistyki. Tym impulsom trzeba poświęcać taką samą, jeśli nie większą, uwagę. Dzieje się tak ze względu na szczególne więzi łączące teologię z tymi typami refleksji: wiele z nich najpierw tworzyło integralną część teologii, a dopiero $z$ biegiem czasu wyemancypowało się do postaci samodzielnych nauk. Taką drogę przeszły teologiczne pytania dotyczące rozumienia tekstu i jego interpretacji, znaczenia historii w przekazie idei, diagnozy doświadczenia wiary itd. Spotkały się one z podobnymi problemami w innych obszarach, które nie miały już konotacji teologicznych. Dzisiaj jako nowe dyscypliny podsuwają teologii nowe rozwiązania. Możliwość ich zastosowania w teologii to znakomite pole wyzwań do krytycznego namysłu dla teologa. Pole, z którego nie powinien rezygnować, nawet za cenę ryzyka pomyłek w krytycznej diagnozie teologicznej. Ryzyko dotyczy oczywiście problemu odpowiedniości metod właściwych dla różnych nauk w odniesieniu do przedmiotu teologii, ostatecznie: do tajemnicy Boga. Ponieważ jednak chrześcijaństwo żyje na fundamencie wiary we Wcielenie, w przemowę Boga w historii, w samowpisanie się Boga w prawidła i ograniczenia ludzkiego języka i ludzkiego rozumu, to obowiązek podejmowania takiego ryzyka pozostanie zawsze udziałem teologii. Dodajmy także, że takie otwarcie na metodologie innych nauk (humanistycznych), szeroko preferowane, stawia przed teologiem duże wyzwanie do zdobywania nowych kompetencjī ${ }^{7}$.

Kwestia prawomocności zainteresowania stosowalnością metod (i rezultatów) nauk pozateologicznych $\mathrm{w}$ teologii nabiera w świetle prawdy o konstytutywnej historyczności Objawienia szczególnej siły. Samo to zainteresowanie może przybierać kształt bardziej charakterystycznych i szczegółowych pytań o relację między absolutem a historią, łaską a naturą, wiarą a wiedzą, całością a częścią. Przywołajmy kilka klasycznych przykładów odnoszących się do zdefiniowanych pojęć dyscyplin. Do rangi problemu standardowego urósł spór o reguły stosowalności badań historycznych i filologicznych w przestrzeni zagadnień teologicznych. Podobnie standardowym zagadnieniem od dawna jest już hermeneutyka, ale do jej drzwi pukają coraz szersze zakresy badawcze opisywane szyldem „kognitywistyka”, w których humanistyka spotyka się z naukami empirycznymi. Niegasnące ognisko wyzwań metodologicznych przedstawiają od lat badania na styku z socjologią i psychologią .

\footnotetext{
7 Por. T. Węcławski, Metodologia teologii, „Nauka” 3 (2004), s. 116-119.

8 J. Majka w swoim opracowaniu z metodologii teologii zwracał szczególną uwagę na taki problem w odniesieniu do zapożyczeń z nauk społecznych (socjologii) w badaniach teologicznych. Patrząc od strony strukturalnej, ten sam problem pojawia się na przykład w badaniach z zakresu duchowości odwołujących się do psychologii. We wszystkich tych przypadkach i im podobnych teologia jako nauka, stając przed koniecznością krytycznej refleksji nad przestrzeganiem reguł naukowego dyskursu, konfrontuje się z zagadnieniem typowym dla badań interdyscyplinarnych: jaki wpływ na jej własną tożsamość, a więc przedmiot i treści badań mają przyjęte metody? Czy nie zniekształcają
} 
O ile ta refleksja skutkuje słusznymi wnioskami, to nie ulega wątpliwości, że najbliższa przyszłość przyniesie dalszy rozwój nauk humanistycznych i społecznych, a wraz z nimi dalsze wyzwania dla teologii i dla krytycznej recepcji metod i treści przez nie prezentowanych, zakładając twórczą i krytyczną debatę.

\subsection{TEOLOGIA JAKO NAUKA KOŚCIELNA KRYTYCZNA WOBEC SIEBIE: NORMATYWNOŚĆ I INTERPRETACJA}

Rozważania nad obowiązkiem krytyczności teologii, wynikającym z jej spotkania z naukami, podprowadzają już do wnętrza drugiej sfery naszego tematu. Teologia jako nauka ma obowiązek być krytyczną, czyli rzetelną w ogólnym sensie naukowości. Ale jej własna specyfika nakłada na nią zupełnie szczególne ramy czy ukierunkowania owego krytycznego oglądu. Z wnętrza życia wiary Kościoła rozlega się przypomnienie, że własnym i niezbywalnym obszarem treściowym teologii chrześcijańskiej pozostaje tajemnica Boga objawiającego się (a więc samoudzielającego się) przez Chrystusa i przyjmowana w wierze. „Teologia [...] opiera się na podstawowym akcie słuchania z wiarą objawionego Słowa Bożego, samego Chrystusa". To słuchanie ma charakter wspólnotowy, to znaczy zakłada uczestniczenie we wspólnocie wiary, rozciągającej się w czasie (dlatego zawsze istotny jest głos Tradycji) i przestrzeni (dlatego ważne jest uwzględnienie wielości dawnych i współczesnych kontekstów uprawianej teologii). Z niego ma wyrosnąć teologia jako intellectus fidei, a więc przedstawienie wiary w sposób zgodny z rozumem, przy czym to rozum uprzednio musi pozwolić na prześwietlenie go światłem wiary.

Jeśli odnieść się tylko do takiego opisu proprium teologii, to już tutaj widać jedno istotne pole dla jej krytycznego uprawiania. Rozpościera się ono w całej historii krytycznych debat w teologii - od początku chrześcijaństwa aż po współczesne dyskusje. Wspomniane podstawowe zadanie teologii, polegające na rozumowym uchwyceniu treści wynikających ze słuchania słowa Bożego, otwiera bowiem szeroką przestrzeń do poszukiwań hermeneutycznych w odczytaniu objawionego słowa, które rozlega się w historii, a równocześnie przestrzeń do konstruowania racjonalnych i uniwersalnych ram dla wyłaniającej się z tego słuchania wypowiedzi o przewyższającej wszystko tajemnicy Boga. Innymi słowy, w całej teologii toczy się krytyczny namysł - zmaganie o rozróżnienie prawdy; angażuje on hermeneutykę jako teorię rozumienia historycznego tekstu oraz metafizykę, którą w tym kontekście widzieć trzeba jako teorię przechodzenia od zmiennej historii ku absolutnej prawdzie Boga. Hermeneutyka i metafizyka nie pozwalają się sprowadzić do jednego,

poznania teologicznego, czy wspierają je? A może właśnie jej własna, od wewnątrz broniona tożsamość domaga się rozszerzenia?

9 Międzynarodowa Komisja Teologiczna, Teologia dzisiaj: perspektywy, zasady i kryteria, Kraków: Wydawnictwo Księży Sercanów DEHON 2021, nr 4. 
tak jak nierozwiązywalne napięcie trwa między poznaniem historii a poznaniem Absolutu - by przywołać tu znaną Lessingową figurę myślową. Teologia potrzebuje obu w równej mierze, gdyż żyje ze słuchania Boga objawiającego się w historii, a w swoim centrum znajduje tajemnicę Wcielenia - universale concretum $^{10}$. Nie mogąc ich pojednać bez reszty inaczej jak tylko w wierze, teologia musi „wytrzymać" widoczne napięcia, a nawet więcej: wskazywać racjonalne perspektywy pojednania. Do tego zobowiązuje ją przyjęte $\mathrm{z}$ wiarą orędzie o Wcieleniu.

Mówiąc jeszcze inaczej, w nawiązaniu do starożytnego rozróżnienia oikonomiatheologia, hermeneutyka związana z odczytywaniem ekonomii historycznego zbawczego działania Boga staje naprzeciwko theologia, poszukującej odpowiedniego $\operatorname{logosu}{ }^{11}$ dla wyrazu niezmiennej prawdy Boga. Tak ujawnia się trwający od wieków spór o prawidłowe ujęcie relacji między tymi dwoma pierwotnymi zadaniami teologii. Oczywiście, ta długo prowadzona debata przyniosła ważne ustalenia treściowe. Ostatecznie stanowią ją dogmaty Kościoła. Ale to właśnie w nich można rozpoznać nie tylko „ustalenia ostateczne”, ale też fakt częściowego tylko pojednania obu perspektyw. Najwyraźniej widać to w fundamentalnych dogmatach - trynitarnym i chrystologicznym. Wyraża się on w odrzuceniu skrajnych interpretacji i równocześnie pozostawieniu otwartej przestrzeni do dalszych poszukiwań.

Metafizyka nadaje ramy wnioskom wysuwanym w drodze czytania i interpretacji historycznego tekstu. Z kolei hermeneutyka kontroluje treści myśli metafizycznej w teologii, określając warunki czytania i interpretacji tekstu ${ }^{12}$. Teologia wciąż znajduje się w takim kołowym procesie rozumienia. Czy będzie on przyspieszać i generować intensywniejsze debaty w przyszłości? Wiele zależy od losów obu elementów tego kręgu. Można z pewnością założyć, że hermeneutyka ma przed sobą burzliwą przyszłość, a to za sprawą wkraczania w jej przestrzenie nauk kognitywnych ${ }^{13}$. Proces ten nie omija już teraz teologii i nie ominie jej w przyszłości. $Z$ drugiej strony pozostaje aktualne pytanie o status myślenia metafizycznego. Czy w pokantowskim, a przyspieszonym z technologiczno-pragmatycznych powodów

10 Kategoria przywołana $\mathrm{z}$ historii teologii przez H.U. von Balthasara; por. zwłaszcza Theodramatik 2. Die Personen des Spiels. 1. Der Mensch in Gott, Einsiedeln: Johannesverlag 1976, s. 186-192, 355-358. Przytoczenia za: E.-M. Faber, Universale Concretum: Zur Auslegung eines christologischen Motivs, „Zeitschrift für Katholische Theologie” 122 (2000), nr 3-4, s. 313. Autorka wskazuje, że interesujący nas wymiar jednania historycznej jednostkowości Chrystusa z absolutnym charakterem prawdy Boga stanowi tylko jeden z czterech poziomów rozumienia tego wyrażenia. Podobnie: por. M. Jóźwik, Hermeneutyka podstawowych pojęć chrystologicznych w teologii Hansa Ursa von Balthasara, „Teologia w Polsce” 7 (2013), nr 2, s. 150-154.

11 Także w tak zaproponowanym terminie „logos” pobrzmiewa historia sporu o relację między Logosem objawionym (wcielonym) a logosem metafizyk(i), między roszczeniem do racjonalnego „uchwycenia” prawdy Boga a uznaniem absolutnego pierwszeństwa i wystarczalności samoobjawienia Logosu Wcielonego.

12 „Tekst” oczywiście należy rozumieć szeroko, ostatecznie jako ekspresję doświadczenia wiary.

13 Jako przykład tego typu diagnozy i wskazanie na jej rozwój por. B. Brożek, Granice interpretacji, Kraków: Copernicus Center Press 2014. 
kryzysie myślenia metafizycznego teologia skutecznie je uratuje nie tylko dla siebie, ale też jako przestrzeń wymiany myśli z naukami? Sygnalizując tylko dyskutowaną od dawna kwestię, czy wielka synteza teologii dokonana przed wiekami na bazie metafizyki arystotelesowsko-tomistycznej może być zastąpiona bądź zmodyfikowana przez inny paradygmat, łatwo spostrzec, że to ze środka wiary płynie wyzwanie do poszukiwania nowej metafizyki - spójnego rozumienia świata i otwarcia w jej ramach jakiegoś przystępu do tajemnicy Boga ${ }^{14}$.

Trudno w tym artykule wchodzić głębiej w zasygnalizowane debaty. Przedstawione napięcie charakteryzuje szeroką panoramę dyskusji prowadzonych od początków teologii chrześcijańskiej, a zintensyfikowanych w teologii katolickiej w ciągu ostatnich stu lat, począwszy od przezwyciężenia kryzysu (anty)modernistycznego, a więc też otwarcia na kulturę sporu toczonego w klimacie pluralizmu myśli filozoficznej. Chodzi zatem raczej o wskazanie, że pole do krytycznej refleksji uchwycone w tej jednej tylko płaszczyźnie napięcia, bardzo charakterystycznej dla chrześcijaństwa skoncentrowanego na „historii Boga z ludźmi”, pozostanie nadal ważnym i rozrastającym się wyzwaniem dla teologii - problemem dla niej zupełnie wewnętrznym, bo wyrastającym z natury historycznego charakteru objawionej prawdy wiecznej.

Jeśli przywołać łatwy do spostrzeżenia, współczesny, ostry spór ,wewnątrzkościelny", określany jako spór między progresywną a konserwatywną wizją chrześcijaństwa, angażujący dziś głównie od strony wyzwań etycznych czy oceny tradycji dyscypliny kościelnej i rozmaitych kwestii organizacyjnych odwołujących się do doktryny, to powinien odsłonić się on teraz jako część zarysowanego wyżej dylematu. Nawet jeśli jego znaczna i najłatwiej spostrzegalna część toczy się na płaszczyźnie popularnej czy publicystycznej, to u jego podstaw znajdują się pytania (i odpowiednio przygotowane odpowiedzi) o granice interpretacji tekstu (biblijnego i Tradycji w ściśle teologicznym, ale też często w szerokim sensie) i o stabilność tez zrodzonych z klasycznej metafizyki, a umocnionych odniesieniem do Ewangelii. Takich sporów z pewnością nie zabraknie w przyszłości.

Przejdźmy wreszcie do szczególnego miejsca na mapie debaty wokół podstawowych założeń uprawiania teologii, zwykle najbardziej kojarzonego z krytyczną funkcją tejże. Chodzi o kwestię umiejscowienia teologa w trójkącie zobowiązań: słuchania wiary ludu Bożego, podporządkowania Urzędowi Nauczycielskiemu i dążenia do odpowiedzialnego opisu intellectus fidei. Nie ma potrzeby omawiania tutaj złożoności tych wzajemnych relacji ${ }^{15}$. W tym miejscu trzeba zapytać, jakie

14 Por. R.J. Woźniak, Metafizyka i Trójca. Teo-ontologia trynitarna pomiędzy apofatyka a katafatyka, w: R.J. Woźniak (red.), Metafizyka i teologia. Debata u podstaw, Kraków: Wydawnictwo WAM 2008, s. 270-304.

15 Kluczową rolę ma tu dokument Kongregacji Nauki Wiary Instrukcja o powołaniu teologa w Kościele (1990). Szczegółowymi dyskusjami zajmuje się wielu autorów. W związku z odniesieniem do samej Instrukcji godne wyróżnienia są treści zawarte w dwuwoluminowym tomie: J. Ratzinger, Opera omnia, t. IX: Wiara w Piśmie i Tradycji. Teologiczna nauka o zasadach, Lublin: Wydawnictwo KUL 2018. 
zobowiązania do krytyczności wobec siebie ma teologia w spotkaniu z tymi instancjami przekazu (poświadczenia) wiary. Otóż, wydaje się, że ważne jest proste podkreślenie, że teologia - jak wiara - jest ze słuchania. To znaczy praca teologa domaga się rzetelności nie tylko w związku z poprawnością metodologiczną, ale też czujności na poziomie duchowo-moralnym. W woli słuchania wiary Kościoła chodzi o uczciwość wewnętrzną w tropieniu w sobie egoistycznych motywów, wpływających na sposób przedstawiania myśli i na rezultaty analiz. Ostatecznie chodzi o wolę autentycznego trwania w wierze Kościoła słuchającego przemowy Boga. Chodzi też o duchowo-moralną wrażliwość na bliźniego, a więc otwartość na taki namysł, który pamięta o Bogu przychodzącym w bliźnim i nie zamienia tego faktu w teoretyczne pryncypium, lecz mierzy się z konkretnym fenomenem spotkania. Wówczas teologia za punkt odniesienia interpretacji obiera prymat miłości Boga i bliźniego. A to wydaje się nieodzownym kluczem do słuchania Objawienia.

Ten subiektywny motyw krytyczności teologii wobec siebie samej, wynikający z istoty Ewangelii, a zarazem wysoce zgodny ze standardami krytycznej pracy naukowej, może być ważnym kryterium oceny jej wartości w przyszłości. Ostatecznie pozwala on bowiem na zbliżenie treści teologii ze sposobem jej uprawiania: teoretycznej refleksji z duchowością oraz z praktyką życia w społeczeństwie. W tej mierze niepotrzebne jest prognozowanie przyszłości - ten wymiar uprawiania teologii zawsze pozostaje ważny.

\section{ROZWINIĘCIE DRUGIE: TEOLOGIA ROZRÓŻNIAJĄCA I OCENIAJĄCA}

\subsection{TEOLOGIA KRYTYCZNA WE WŁASNYM DOMU WIARY KOŚCIOŁA}

Odwracamy teraz perspektywę prezentacji: teologia nie tylko jest krytyczna wobec siebie w słuchaniu słowa Bożego, lecz w Kościele ma nade wszystko misję krytycznej recepcji, interpretacji i oceny wyrazu wiary czy jej głoszenia, a także krytycznej oceny okoliczności, w których żyje wspólnota wiary. Konkretnie przejawia się to w wielu przestrzeniach, ale najbardziej wyraźnie w zakresie problemów wiary i moralności wynikłych z pytań współcześnie zadawanych. Wydaje się, że paradoksalnie narasta obecnie dążenie do uzyskania wiążącej i możliwie szybkiej odpowiedzi na takie pytania. Proces zdobywania odpowiedzi może jednak wymagać cierpliwej pracy i zasadniczo nie zawsze musi zostać definitywnie zakończony. Nie może on w każdym razie pomijać debaty teologicznej, a w niej szczególnie sztuki krytycznego rozróżniania. Innymi słowy, jeśli można spotkać oczekiwania rozstrzygnięć ze strony autorytetu kościelnego, to winny takowe być poprzedzone debatą teologiczną i oparte na jej efektach. Można tu dodać, że zawsze warto 
rozważyć, czy dane pytanie domaga się autorytatywnych odpowiedzi kościelnych, a także jaką formę dana odpowiedź powinna przybrać. Jeśli w wyjaśnienie nowego zagadnienia zaangażowana jest jakaś instancja Urzędu Nauczycielskiego, to pojawia się pytanie, czy taka kwestia może być nadal przedmiotem dyskusji teologicznej. Z zasady tak, ze względu na konieczność interpretacji tekstu, który z chwilą promulgacji staje się już tekstem historycznym. Oczywiście, promulgowana wypowiedź autorytetu kościelnego nie jest tylko opinią teologiczną, lecz eklezjalnie wiążącą na odpowiednim szczeblu - treścią. Jednak rozumienie Kościoła jako wspólnoty interpretacji pozwala na włączenie także tej wypowiedzi w ciąg dalszego procesu rozeznawania.

Zatem Urząd Nauczycielski strzeże wiary ludu Bożego między innymi właśnie dzięki krytycznej (czyli diagnozującej i oceniającej) pracy teologów. W tym zaś procesie teolog $\mathrm{w}$ nieunikniony sposób bierze na siebie napięcia związane $\mathrm{z}$ interpretacją i oceną treści oraz diagnozą ich kontekstów.

Tak zaznaczona defensywna funkcja krytyczna teologii powinna być przede wszystkim traktowana jako pochodna zadania ofensywnego, lepiej powiedzieć w Kościele: profetycznego wskazywania drogi, wyprzedzania pytań, podsuwania rozwiązań, które mogą pozwolić przedstawić jakiś moment wiary adekwatnie do współczesnych wyzwań. Tutaj cenne są zarówno syntetyczne wizje, budujące jedną, uniwersalną perspektywę, jak i projekty cząstkowe, które szczególnie wyraźnie pokazują się w teologiach kontekstualnych (tak w kontekście regionu, jak i specyfiki czasów). Nawet jeśli te ostatnie nie stają się częścią głównego nurtu, to mają szanse zostawić ważny ślad we wrażliwości na rozległość współczesnej problematyki wiary i ostatecznie przywołać w nowy sposób prawdę o Bogu „,zawsze większym", a tym samym przeciwdziałać niebezpieczeństwu skostnienia. To szczególnie ważne w sytuacji dynamicznie zmieniającego się świata.

Tutaj zatem można prognozować, że w przyszłości nastąpi dalszy rozwój koncepcji teologicznych spoza „głównego nurtu”, jak to dzieje się już od dziesięcioleci. Przyniosą one niestandardowe diagnozy i oceny dotychczasowych form życia wiary oraz otaczającego świata. Na tym tle z pewnością będą rozwijać się napięcia, w których jak zawsze możliwe jest pojawienie się twórczego potencjału, ale też obok niego siły destrukcyjnej. Wyważenie takich „zysków” i „strat” płynących z nowych kierunków będzie również przedmiotem debaty. Spoglądając szerzej: wyzwania związane z akceptacją pluralizmu w teologii i zarazem troski o jej jedność z pewnością nadal będą źródłem kolejnych krytycznych opinii.

Godnym wyróżnienia, szczególnym wymiarem krytycznych zadań teologii we wspólnocie wiary jest jej zaangażowanie w dialog ekumeniczny. We wspomnianym problemie ,jedność wiary - pluralizm teologiczny” dialog ekumeniczny wyróżnia się tym, że bada on granice określone w złożonych procesach historyczno-doktrynalnych. Jak się okazuje, próbuje się w teologii ekumenicznej przekroczyć te granice przez podejmowanie wysiłków interpretacyjnych. Dotychczasowe rezultaty 
dialogu ekumenicznego wskazują, że to zaakceptowany pluralizm teologiczny może przysłużyć się do budowania jedności wiary ${ }^{16}$.

$\mathrm{Na}$ koniec tej części dodajmy, wracając do podstawowego tenoru niniejszej refleksji, zwracającego uwagę na dynamiczny, otwarty charakter poszukiwania prawdy teologii: ze słuchania słowa Bożego rozciągniętego w historii, z debat, orzeczeń i dalszych dyskusji nie wynika prosty, ilościowy przyrost wiedzy teologicznej. Taki przyrost byłby owocem szczególnie pojętej krytyczności debaty teologicznej, zasadzającej się na ciągłym uzupełnianiu wiedzy, a nie na odnawianiu jej interpretacji. Jednak taki obraz teologii się wyczerpał. Wyrastał on z zamrożenia hermeneutycznych i metafizycznych podstaw jej uprawiania. Po rozpadzie tego modelu, czyli po przezwyciężeniu kryzysu modernistycznego, postawa krytyczna w teologii, w obrębie wewnętrznych reguł jej uprawiania, awansowała do roli „regulatora” napięć, narzędzia do utrzymywania równowagi w niezliczonych dylematach. Ponieważ w obrębie doktryny wiary istnieje fundament doktrynalny, ale nie ma jednego wystarczającego systemu teologicznego, a więc jest szerokie pole do uprawiania różnych teologii, to właśnie wzajemna, krytyczna wymiana myśli pozwala na staranie o dynamiczną równowagę. Zgoda co do istoty doktryny wiary stanowi fundament dla jedności, w której obrębie wciąż jest miejsce na twórczy spór.

\subsection{TEOLOGIA KRYTYCZNA WOBEC ŚWIATA}

Pozostaje do przedstawienia czwarty sektor, w którym poszukujemy krytycznych funkcji teologii - w zwróceniu jej „ku światu”. Wróćmy na chwilę do punktu wyjścia, wskazującego na proprium teologii: własnym i niezbywalnym obszarem treściowym teologii chrześcijańskiej pozostaje tajemnica Boga objawiającego się przez Chrystusa i przyjmowana w wierze. Jeśli istnieje prawomocna funkcja krytyczna teologii „wobec świata”, to właśnie ten moment tożsamości teologii powinien ją wyjaśniać. Oznacza to, że tworzona przez teologię krytyczna diagnoza powinna $\mathrm{w}$ ten sposób być zrozumiała z punktu widzenia wiary. Pozostaje jednak pytanie, $w$ jakiej mierze może ona podnosić roszczenie do uniwersalnego znaczenia. Gdzie w ogóle poza teologią może być stosowana?

Przypomnienie tożsamości teologii przywołuje różnicę między nią a naukami nowożytnymi. Ta różnica w rozmaitych przypadkach może być przyczyną sporów odnoszących się do pojęcia naukowości, a niekiedy także prowokować spory

16 To przede wszystkim rozpoznanie płynące z rezultatów najważniejszego porozumienia ekumenicznego, czyli luterańsko-katolickiej Wspólnej deklaracji w sprawie nauki o usprawiedliwieniu. Por. L. Ullrich, Differenzierter Konsens und Komplementarität: mögliche Wege zur Einheit in Verschiedenheit, w: H. Wagner, H. Meyer (red.), Der neue Mensch in Christus. Hellenistische anthropologie und Ethik im Neuen Testament, Freiburg-Basel-Wien: Herder 2000, s. 102-135. 
o prawomocność treści poznania. Spór powinien być narzędziem poznawczego postępu. Jednak na tej linii nie jest on dla teologii łatwy. Zwróciliśmy już uwagę, że dawno temu (patrząc w skali czasu ukonstytuowania się nauk nowożytnych) teologia i nauki szczegółowe wyszły z wzajemnej nieufności, głównie dzięki uznaniu wzajemnej autonomii, odrębności przedmiotu i metod. Ale obecny, ogromny postęp nauk szczegółowych i technologiczna skuteczność wielu ich gałęzi łatwo prowadzą do powrotu klimatu scjentyzmu, w którym uprawniony metodologiczny ateizm nauk urasta do zasady widzenia rzeczywistości. Zapalnym punktem bywa $\mathrm{z}$ drugiej strony powrót niewystarczająco zreflektowanego teologicznego myślenia, które wkracza ze swoimi postulatami w przestrzeń nauk szczegółowych. Te sprawy jednak relatywnie łatwo zidentyfikować ${ }^{17}$. Teologia ma tu własne krytyczne zadanie do spełnienia zarówno w kwestii identyfikacji ideologicznego scjentyzmu, jak i teologicznych projektów naruszających autonomię nauk.

Trudniejsze wydaje się $\mathrm{w}$ perspektywie spotkania $\mathrm{z}$ naukami rozwijanie dyskursu na pewnych polach wspólnych, czyli na temat teologicznych pewników, podpartych uniwersalizującym językiem filozofii, a równocześnie problematyzowanych czy nawet kwestionowanych przez rozwijające się nauki szczegółowe. Takie przestrzenie wyłaniają się raz po raz. Należą do nich kwestie tak fundamentalne, jak na przykład w antropologii: podmiotowość, wolność, moralność, sumienie, tożsamość płciowa. Tutaj wydaje się bardzo ważne, by teologia poszukiwała nowych, pogłębionych i realnie nawiązujących do stanu wiedzy argumentów do krytycznej debaty. Nie obywa się to bez potrzeby równoczesnej dyskusji na temat jawnych bądź ukrytych filozoficznych założeń metod prowadzonych badań naukowych.

Zostało już wspomniane, że teologia zawsze będzie zobowiązana do mierzenia się z obrazem świata wytworzonym przez nauki współczesne. Pryncypialnie i odpowiednio do swoich czasów wyznają taką tezę tak samo dawne autorytety, na przykład Orygenes, Augustyn, Anzelm, Tomasz, budując swoje spojrzenie teologiczne na podstawie współczesnego im wyobrażenia świata. To jest niezmiennie miejsce do krytycznego myślenia, owocnego sporu o kształt samej teologii. Powtórzmy jednak, że od razu tutaj pojawia się przestrzeń do krytycznej oceny nauk szczegółowych. Ma ona główne zadanie do spełnienia tam, gdzie wiedza naukowa zamienia się w ideologiczną konstrukcję, eliminującą pytania ostateczne, bo wtedy również zaczyna być traktowana jako ersatz metafizyki i fundament dla rozwiązań etycznych i apriorycznej deprecjacji religii.

Teologia ma oczywiste zadanie czuwania nad tym problemem przekraczania granic kompetencji. Wiemy to $\mathrm{z}$ historii problematyki. Nie zawsze jest to jasne w sytuacji, gdy w przestrzeni dyskusji pojawiają się zupełnie nowe tematy. A tych dziś nie brakuje i z dużym prawdopodobieństwem można przypuszczać, że w przyszłości takich problematycznych obszarów będzie więcej.

17 P. Polak, Teologia nauki w perspektywie metodologicznej, s. 27-29. Warto odesłać także do innych opracowań tego tomu. 
Krytyczne funkcje teologii w stosunku do świata nie mogą jednak ograniczać się do relacji z naukami. Wielokrotnie podnoszone twierdzenie, że teologia ma misję krytycznej oceny różnych przejawów życia ludzkiego, nie jest oczywiste, dopóki nie dokona się istotnego rozróżnienia. Teologia jako intellectus fidei jest właściwym narzędziem, by z perspektywy wiary dokonywać ocen zjawisk (postaw, moralności, uznawanych prawd) funkcjonujących także poza sferą wspólnoty wiary. Oceny czy diagnozy tak dokonane będą mogły mieć walor prawdziwości dla ludzi podzielających wiarę, natomiast problematyczny będzie odbiór takich ocen przez osoby stojące poza wiarą Kościoła. Już w starożytności, w związku z ewangelizacją, wiedziano, że trzeba odnajdywać takie motywy wyjaśniające wiarę i z niej płynącą ocenę świata, które okażą się co najmniej przekonujące dla niewierzącego (jeśli nie uzna ich za po prostu prawdziwe). W teologii katolickiej udało się zbudować gmach uzasadnień wiary, a także diagnoz dotyczących całego świata powołujących się na zgodność fides et ratio. Teoretyczne wyjaśnienia zgodności wiary i rozumu prezentowane w Kościele napotykają wszelako na jeden problem w odniesieniu do ich skuteczności: są wyjaśnieniami teologicznymi, a więc poza środowiskiem wiary nie są oczywiste. Jeśli powołują się na filozofię, czyli zgłaszają roszczenie uniwersalnego rozumu, to tym samym wystawiają się na krytykę pojęcia uniwersalności rozumu (lub na niezgodę wobec absolutyzacji tzw. filozofii chrześcijańskiej). Tym samym w praktyce okazuje się, że krytyczny głos teologii pod adresem „świata" nie znajduje u adresata zobowiązujących podstaw do ich przyjęcia.

Wspomnieć też trzeba fundamentalny problem, który aż po kryzys modernistyczny naznaczył samą refleksję teologiczną w odniesieniu do jej zdolności oceny „świata”. Otóż, twarde odizolowanie natury i nadprzyrodzoności, uznanie natury jako możliwej do samodzielnego spełnienia poza łaską prowadziło do izolacji sfery nadprzyrodzoności od życia w przestrzeni ,poza łaską”. W tej koncepcji krytyka ze strony świata nie mogła dosięgnąć Kościoła i jego teologii, ale też z trudem była możliwa krytyka świata ze strony teologii. Przezwyciężenie tego problemu na przedpolu Vaticanum II pomogło w otwarciu teologii i Kościoła na świat, ale tylko w ograniczonym stopniu mogło ono liczyć na wzajemność. Świat nie musiał interesować się ani nie miał podstaw, by rozumieć, co znaczy przezwyciężenie kryzysu natura - nadprzyrodzoność.

Problem ten widać dzisiaj bardzo wyraźnie. Teologia jest od strony koncepcji krytyki świata przygotowana i formułuje krytyczne diagnozy dotyczące wielu aspektów życia z wolą osiągnięcia jak najszerszego kręgu słuchaczy. Tymczasem społeczeństwa, w których doszło do erozji życia chrześcijańskiego, coraz mniej interesują się diagnozami kościelno-teologicznymi. Teza o zgodności fides et ratio albo też prawdy Objawienia z prawdą historyczną z punktu widzenia kogoś znajdującego się poza wiarą Kościoła domaga się tak samo jak inne idee wykazania swej wiarygodności. Diagnozy teologiczne dokonywane na forum dyskursu społecznego muszą okazać swoją wiarygodność w ramach tegoż dyskursu, jako że pożegnał się on z autorytetem religii. Dyskurs nowożytności utracił równocześnie pierwotną 
naiwność oświeceniową, zakładającą uniwersalne roszczenia autonomicznego rozumu; wskutek tego jednak w kręgu podejrzeń znalazły się także roszczenia do uniwersalności twierdzeń filozoficznych przychodzących od strony chrześcijaństwa.

Jaka zatem może być skuteczność krytycznych diagnoz teologicznych wobec świata, przygotowywanych z największą starannością, ale opartych na teologicznej topice i metodologii? Ojcowie Vaticanum II, redagując konstytucję Gaudium et spes, diagnozującą kondycję wybranych przejawów życia ludzkiego, zwracali się $z$ ocenami nie tylko do Kościoła, ale też do wszystkich ludzi ${ }^{18}$. To spektakularne uznanie, że nie wszyscy muszą się utożsamiać z wiarą Kościoła, by słuchać Soboru, ale wszyscy mogą być adresatami jego przesłania, ostatecznie opierało się na przezwyciężeniu „piętrowego" schematu natura - nadprzyrodzoność. Na tym założeniu oparła się także w zasadzie cała teologia posoborowa. Jej początkowy sukces polegał być może na przyjęciu hermeneutyki uznania ${ }^{19}$, czyli dość jednostronnym podkreślaniu zalet epoki nowoczesnej. Ale gdy pojawiły się powody do negatywnej oceny wielu zjawisk, powrócił problem powszechnej akceptacji. Ostatecznie zatem można potwierdzić myśl zawartą w nagłówkach współczesnych dokumentów kościelnych: adresatami orędzia wynikającego z Ewangelii, a w nim także krytycznych analiz poza członkami Kościoła są „wszyscy ludzie dobrej woli”. Krytyczna ocena świata w argumentacji kościelno-teologicznej, wspartej odwołaniem do ,argumentów rozumowych”, rozbija się o tezę o zakwestionowanym rozumie uniwersalnym. Musi więc zatrzymać się w oczekiwaniu na wolną odpowiedź „ludzi dobrej woli”. Profetyczne przesłanie chrześcijaństwa, a wraz z nim krytyczne analizy teologiczne czekają na wolną odpowiedź słuchacza. Wydaje się, że to ten model funkcjonowania teologii jako uczestnika otwartego dyskursu w społeczeństwie przyszłości ma swoją szansę.

\section{UWAGI KOŃCOWE}

Trudno podsumować refleksję, która zgodnie z zapowiedzią jest otwartym projektem, zbiorem impulsów do namysłu i dyskusji. Chodziło w niej o uchwycenie najbardziej ogólnie ujętych trendów, mających wpływ na realizację krytycznej funkcji teologii w przyszłości. Podstawowa uwaga, która się nasuwa, wiąże się z początkowym zamysłem tej prezentacji. Otóż, wydawało się, że przyjęta tu systematyka materiału pomoże nazwać odrębne zagadnienia. Okazało się, że są

18 Por. KDK 2.

19 Por. I. Gabriel, Christliche Sozialethik in der Moderne. Der kaum rezipierte Ansatz von Gaudium et spes, w: J.-H. Tück (red.), Erinnerung an die Zukunft. Das Zweite Vatikanische Konzil, Freiburg-Basel-Wien: Herder 2012, s. 542-545. 
to zagadnienia mocno ze sobą powiązane. Ad intra i ad extra teologii - w obu wyróżnionych wymiarach - stoją blisko siebie. Krytyczność teologii jest miarą jej żywotności. Sztuka rozróżniania i oceny zjawisk, idei, nowej wiedzy, zadana teologii jako dziedzinie zainteresowanej całym światem w aspekcie jego tożsamości stworzenia i naznaczenia zbawieniem, otwiera ogromne obszary refleksji.

\section{WYKAZ SKRÓTÓW}

KDK - Sobór Watykański II, Konstytucja duszpasterska o Kościele w świecie wspótczesnym ,Gaudium et spes”

\section{KRYTYCZNE FUNKCJE TEOLOGII W PERSPEKTYWIE PRZYSZŁOŚCI}

\section{Streszczenie}

W poszukiwaniu krytycznych funkcji teologii daje się zauważyć narastającą ilość dylematów, przychodzących zarówno z wnętrza teologii, jak i ze współczesnej wiedzy o świecie, z którymi teologia musi się mierzyć, nie tylko udzielając oczekiwanych odpowiedzi, ale też konstruując własny wykład wiary: odpowiedni dla czasów współczesnych i zgodny z Tradycją wiary. Trudno tak obszerny materiał przedstawić w krótkim artykule inaczej niż na wysokim poziomie ogólności. Kluczem do usystematyzowanego zarysowania tych zagadnień jest spostrzeżenie, że zadania teologii można rozpatrywać z czterech różnych perspektyw, opartych na schemacie zadań ad extra i ad intra. Silny akcent zostaje postawiony na spotkanie teologii z naukami nowożytnymi. Próba podjęcia prognoz dotyczących przyszłości jest oparta na analizie sytuacji współczesnej w teologii i na ekstrapolacji istniejących trendów w najbliższą przyszłość.

Słow a kluczowe: metodologia teologii, teologia a nauki, krytyczne funkcje teologii.

\section{THE CRITICAL FUNCTIONS OF THEOLOGY FOR THE FUTURE}

\section{Summary}

In the search for the critical functions of theology, we can find a growing number of dilemmas, which come from the theology itself and from the modern knowledge about the world, which theology has to face, not only offering expected answers, but also formulating its own Christian doctrine proper for contemporary times and consistent with the Tradition of faith. The only way to present such a broad and difficult problem in a short paper is through a general perspective. The key to the systematization of the problem is by observing that the tasks of theology can be seen from four different perspectives, according to the distinction 
ad extra-ad intra. A strong emphasis is put on the encounter between theology and science. The attempt to make predictions about the future is based on analysis of the contemporary situation in theology and on the extrapolation of existing trends for the near future.

K e y w or d s: methodology of theology, theology and science, critical functions of theology.

\section{KRITISCHE FUNKTIONEN DER THEOLOGIE \\ IN DER PERSPEKTIVE DER ZUKUNFT}

\section{Zusammenfassung}

Auf der Suche nach den kritischen Funktionen der Theologie kann man eine wachsende Zahl von Dilemmata feststellen, die aus dem Inneren der Theologie und aus dem zeitgenössischen Wissen über die Welt resultieren, und denen sich die Theologie stellen muss, indem sie nicht nur erwartete Antworten gibt, sondern auch ihre eigene Interpretation des Glaubens konstruiert - und dies zeitgemäß und in Übereinstimmung mit der Glaubenstradition. Es ist schwierig, solch umfangreiches Material in einem kurzen Artikel darzustellen; möglich ist es nur auf einer hohen Ebene der Allgemeinheit. Der Schlüssel zu einer systematischen Darstellung dieser Fragen ist die Feststellung, dass die Aufgaben der Theologie aus vier verschiedenen Perspektiven betrachtet werden können, basierend auf dem Schema der Aufgaben ad extra und ad intra. Ein bedeutender Schwerpunkt liegt auf der Begegnung zwischen Theologie und den modernen Wissenschaften. Auf der Grundlage der Analyse der gegenwärtigen Situation in der Theologie und der Extrapolation bestehender Trends in die nahe Zukunft wird der Versuch einer Zukunftsprognose unternommen.

S chlüs se lw ört er: Methodologie der Theologie, Theologie und Wissenschaften, kritische Funktionen der Theologie.

\section{BIBLIOGRAFIA}

Barbour I.G., Jak układaja się stosunki między nauka a teologia? Część I, tłum. S. Cyran i in., „Zagadnienia Filozoficzne w Nauce” 15 (1993), s. 3-22.

Barbour I.G., Jak układają się stosunki między nauka a teologią? Część II, tłum. S. Cyran $\mathrm{i}$ in., ,Zagadnienia Filozoficzne w Nauce” 16 (1994), s. 3-22.

Brożek B., Granice interpretacji, Kraków: Copernicus Center Press 2014.

Faber E.-M., Universale Concretum: Zur Auslegung eines christologischen Motivs, „Zeitschrift für Katholische Theologie" 122 (2000), nr 3-4, s. 299-316.

Gabriel I., Christliche Sozialethik in der Moderne. Der kaum rezipierte Ansatz von Gaudium et spes, w: J.-H. Tück (red.), Erinnerung an die Zukunft. Das Zweite Vatikanische Konzil, Freiburg-Basel-Wien: Herder 2012, s. 537-553.

Heller M., Nowa fizyka i nowa teologia, Tarnów: Biblos 1992. 
Jóźwik M., Hermeneutyka podstawowych pojęć chrystologicznych w teologii Hansa Ursa von Balthasara, „Teologia w Polsce” 7 (2013), nr 2, s. 141-155.

Kongregacja Nauki Wiary, Instrukcja o powołaniu teologa w Kościele (24 V 1990), http://www.vatican.va/roman_curia/congregations/cfaith/documents/rc_con_cfaith_ doc_19900524_theologian-vocation_pl.html [dostęp: 22 V 2021].

Majka J., Metodologia nauk teologicznych, Wrocław: TUM 1995.

Międzynarodowa Komisja Teologiczna, Teologia dzisiaj: perspektywy, zasady i kryteria, Kraków: Wydawnictwo Księży Sercanów DEHON 2012.

Polak P., Teologia nauki w perspektywie metodologicznej, w: J. Mączka, P. Urbańczyk (red.), Teologia nauki, Kraków: Copernicus Center Press 2015, s. 25-56.

Ratzinger J., Opera omnia, t. IX: Wiara w Piśmie i Tradycji. Teologiczna nauka o zasadach, Lublin: Wydawnictwo KUL 2018.

Sobór Watykański II, Konstytucja duszpasterska o Kościele w świecie współczesnym „, Gaudium et spes", Poznań: Pallottinum 2002, s. 526-606.

Ullrich L., Differenzierter Konsens und Komplementarität: mögliche Wege zur Einheit in Verschiedenheit, w: H. Wagner, H. Meyer (red.), Der neue Mensch in Christus. Hellenistische anthropologie und Ethik im Neuen Testament, Freiburg-Basel-Wien: Herder 2000, s. 102-135.

Węcławski T., Metodologia teologii, „Nauka” 3 (2004), s. 101-120.

Wicks J., Wprowadzenie do metody teologicznej, Kraków: Wydawnictwo WAM 1995.

Woźniak R.J., Dogmatyka w perspektywie interdyscyplinarnej. Prolegomena teoretyczno-metodologiczne, w: R.J. Woźniak (red.), Dogmat i metoda. Wprowadzenie do badań interdyscyplinarnych w teologii dogmatycznej, Kraków: Wydawnictwo WAM 2021, s. 17-50.

Woźniak R.J., Metafizyka i Trójca. Teo-ontologia trynitarna pomiędzy apofatyka a katafatyka, w: R.J. Woźniak (red.), Metafizyka i teologia. Debata u podstaw, Kraków: Wydawnictwo WAM 2008, s. 270-304.

Jacek Kempa - duchowny Kościoła rzymskokatolickiego (archidiecezja katowicka), doktor habilitowany nauk teologicznych, profesor uczelni, pracownik naukowy Wydziału Teologicznego Uniwersytetu Śląskiego w Katowicach, specjalista z zakresu teologii dogmatycznej. Prodziekan ds. nauki w latach 2012-2019, od 2020 roku dziekan Wydziału. Członek Towarzystwa Teologów Dogmatyków (wiceprezes w latach 20112017), członek Europejskiego Stowarzyszenia Teologii Katolickiej, w latach 2011-2018 redaktor naczelny „Śląskich Studiów Historyczno-Teologicznych”. Badania naukowe i publikacje w zakresie: soteriologia średniowieczna i współczesna, antropologia teologiczna, hermeneutyka teologiczna. Wybrane publikacje: Konieczność zbawienia. Antropologiczne założenia soteriologii Anzelma z Canterbury (2009), Zbawieni przez ofiare?? Historia i perspektywy centralnej kategorii soteriologicznej (redaktor, 2012), Słowo, doświadczenie, tajemnica (redaktor z M. Giglok, 2015), Poznanie Boga w historii: debata między Josephem Ratzingerem a Walterem Kasperem (2017), Zbawienie wobec historii. Próba teologicznej rehabilitacji pojęcia utopii (2018), Relacje między modelami w soteriologii. Glossa do dyskusji o komplementarności (2020). Adres do korespondencji: jacek.kempa@us.edu.pl. 